Journal of Nat. \& App. Sci.
Volume 3, Issue 2, 19-25, 2020

\title{
Immunomodulatory Effects of Moringa Oleifera Leaf Meal (MOLM) against Newcastle Disease in Broilers
}

\author{
Madeeha AKRAM $^{1}$, Ijaz SALEEM ${ }^{2}$, Muhammad FARHAB ${ }^{3 *}$, Zubair LUQMAN ${ }^{4}$ \\ ${ }^{1}$ Department of Clinical Medicine and Surgery, University of Agriculture Faisalabad, Pakistan \\ ${ }^{2}$ Department of Pathology, Faculty of Veterinary Science, University of Agriculture Faisalabad, Pakistan \\ ${ }^{3}$ Department of Basic Sciences, University College of Veterinary and Animal Science, The Islamia University of Bahawalpur, Pakistan \\ ${ }^{1}$ https://orcid.org/0000-0003-4187-468X \\ ${ }^{2}$ https://orcid.org/0000-0003-4012-0704 \\ ${ }^{3}$ https://orcid.org/0000-0003-2519-6268 \\ ${ }^{4}$ https://orcid.org/0000-0002-6482-6448 \\ *Corresponding author: Farhab.dvm@gmail.com
}

Etlik Piliçlerde Moringa Oleifera Yaprak Ununun (MOLM) Newcastle Hastalığına Karşı İmmünomodülatör Etkileri

\section{Araştırma Makalesi}

Tarihçe:

Alınıș: 16 Mayıs 2020

Kabul: 7 Ağustos 2020

Online Yayınlanma: Aralık 2020

\section{Anahtar Kelimeler:}

Moringa Oliefera

Bağışıklık

Hematoloji

Newcastle hastalığ

Etlik piliç

Farklı düzeyler

\begin{abstract}
ÖZET
Etlik piliçlerde immünomodülatör etkiler açısından Moringa oleifera yaprak ununun (MOLM) etkinliğini kontrol ettik. Çalışmada herbirinde 12 hayvan olan 4 grup oluşturulmuş, toplam 144 hayvan, 12 altgruba ayrılmıştır. Denemede Moringa oleifera yaprak ununun (MOYU) farklı düzeylerdeki (\%0, 2, 4 ve 6) etkisi araştırılmıştır. Hayvanlar 14, 21. Ve 35.gün kesilmiş, hematolojik parametrelerin tespiti için kanları alınarak serumları çıkartılmıştır. Ayrıca HA / HI kullanılarak antikor titresinin bağışıklık sisteminin Newcastle Hastalığına karşı antikor üretmedeki etkinliğini kontrol edilmiştir. Çalışmada Diet b, maksimum canlı ağırlık kazancına ulaşırken; Diet $\mathrm{D}$, en düşük canlı ağırlık kazancına sahip olmuştur. Maksimum yem tüketimi Diet A grubunda; en düşük yem tüketimi de Diet D grubunun yemiyle beslenen hayvanlarda görülmüştür. Diet B'de yemden yararlanma oranı iyileşirken; Moringa oleifera katılmayan grupta en yüksek yemden yararlanma oranı tespit edilmiştir. Yemlere Moringa katkısı, etlik piliçlerde bağışıklık parametrelerini artırken; hastalıkla mücadele de başarılı olmalarını sağlamış; kümes hayvanları için tavsiye edilen bir yem katkısı olmuştur. Denemede Moringa oleifera yaprak ununun karma yeme optimum katılma düzeyinin $4 \mathrm{~g} / \mathrm{kg}$ olduğu da tespit edildi.
\end{abstract}

Immunomodulatory Effects of Moringa Oleifera Leaf Meal (MOLM) against Newcastle Disease in Broilers

\section{Research Article}

\section{History:}

Received: 16 May 2020

Accept: 7 August 2020

Available online: December 2020

\section{Keywords:}

Moringa Oliefera

Immunity

Hematology

Newcastle disease

Broilers

Varying concentration

\begin{abstract}
We checked the efficacy of Moringa oleifera leaf meal (MOLM) for immunomodulatory effects in broilers. 144 birds that were divided into 4 groups having 12 birds each that were further subdivided into groups of 12 . Such that treatment groups were D; receiving 0\%, divided into replicates D1, D2, D3 while similar divisions of group A, B and C received 2, 4 and $6 \%$ of MOLM infused in their feed as an additive supplement. The birds were slaughtered at $14^{\text {th }}, 21^{\text {th }}$ and $35^{\text {th }}$ day and blood as well as serum was collected for the sake of hematological parameters and to check the antibody titer using HA/HI checking for effectiveness of immune system at producing antibodies against Newcastle Disease, which the birds were vaccinated against. Diet B has maximum weight gain fed while Diet D has lowest weight gain, which was a control group. Maximum feed intake was with diet A while lowest feed intake with diet D. Improved FCR was with diet B whereas the highest feed conversion ratio (FCR) was observed in broilers fed diet without Moringa oleifera supplementations. It was concluded that Moringa
\end{abstract}


infused in feed does enhance immune parameters of broilers, making them better at combating diseases, making Moringa a viable dietary supplement for commercial poultry. It was also found that the optimal dose of Moringa in MOLM is $4 \mathrm{~g} / \mathrm{kg}$ feed.

To Cite: Akram M., Saleem I., Farhab M., Zubair L. Immunomodulatory Effects of Moringa Oleifera Leaf Meal (MOLM) against Newcastle Disease in Broilers. Osmaniye Korkut Ata Üniversitesi Fen Bilimleri Enstitüsü Dergisi 2020; 3(2): 19-25.

\section{Introduction}

Poultry industry is one of the wide spread poultry industry in all over the world. The poultry meat production is rapidly increasing up to $4 \%$ annually [1]. Medicinal plants have played an important role for the prevention of many poultry diseases. Almost $25 \%$ medicines used in the poultry industry are extracting from the plants as Moringa oleifera is usually used as herbal plant cultivated for purpose of medicine in all over the world [2].

Moringa oleifera belonged to Moringaceae family which is also referred to as drum stick tree. Almost all medical plants have good properties like anticancer, cardiovascular, anti-asthmatic and antioxidant. Extract of Moringa oleifera has nutritive values [3].

Moringa oleifera seeds and leaves are rich sources of vitamins C and B and lysine [4]. Moringa oleifera is rich in iron. Seeds are used for several soap making and cosmetic purposes. Quality of Moringa oleifera oil extract is better than olive oil [5]. With sunflower meal, it enhances the feed intake, feed conversion ratio and growth rate of birds. Up to $20 \%$ Moringa oleifera used in the layer birds lead to increase in feed intake, layer performance and egg size [6]. It is drought resistant tree with rapid growing property. It also used as fodder for livestock an adjuvant, a natural micronutrient fluid [7]. Moringa oleifera grows in hot climate, loam soil $5-7,7 \mathrm{pH}$ of soil, $30-48^{\circ} \mathrm{C}$. Extract of Moringa oleifera has no significant effect on the broiler chick performance, feed utilization and weight gain. [8]. M. oleifera is used as a cheap, highly digestible and highly bioavailable protein source [9] that may have side effects if used in more than that of the required concentration [10].

M. oleifera has ability to improve hair and skin, lowering blood pressure and blood sugar level, aids in hypotension, skin disorders and diabetes. Seeds of Moringa oleifera are full of flocculants which have ability to enhance water quality.

These seeds are utilized for treating in many purposes such as hypertension, arthritis and sexually transmitted disorders. And also oil extract of seeds used in enhancing milk quality and soil fertility [5]. Moringa oleifera also having antifungal and antibiotics properties against the staphylococcus aureus and Pseudomonas aeruginosa. It is used in the treatment of anemia. Its bark is used for cardiac problem. Its leaves have tocopherol and carotenoid which prevent free radical damage. M. oleifera is used for reduction of cholesterol level in eggs of layers [9]. Moringa oleifera seeds and leaves boost up the immunity. It is also used as antimicrobial agent in ponds [4]. Moringa oleifera is an antibiotic growth promoter [11, 12]. Moringa oleifera increases numbering of phagocytic cells and used to decrease the levels of carbon from blood. It facilitates phytate breakdown by action of phytase enzymes which lead to absorption of phosphorus [13]. Moringa oleifera plants treats Hepatitis B infection in humans [14].

MOLM is also a good source of flavonoids, carotenoids and ascorbic acid [15]. Moringa oleifera leaf meal (MOLM) decreases intake but increases feed conversation ratio (FCR) in poultry [16]. It has high production rate [17]. Moringa oleifera extract up to ratio of $25 \%$ used in poultry feed did not cause any negative effect [18]. MOLM having the positive influences on growth performances and serum biochemistry of starter chicks and also could be integrated at $7,8 \%$ in broiler diets without any destructive consequences on blood chemistry and growth rate of chickens.

Newcastle disease not only affects the egg production but also reduces the quality of eggs and bird performance [19] and is a major threatening and demoralizing disease in the poultry production. We evaluated the efficacy and immunity of Moringa oleifera leaves against ND virus in broiler at different concentrations and to check effect of Moringa oleifera on hematology parameters. 
like pack cell volume and hemoglobin concentration. Pack cell volume was determined by standard procedure of micro-Hematocrit method [20]. Sahile's and Drabkin method was adopted to calculate the hemoglobin concentration.

\subsection{Heamagglutination and Heamagglutination Inhibition Test}

Birds were slaughtered at $14^{\text {th }}, 21^{\text {th }}$ and $35^{\text {th }}$ day of age and also blood was collected for further immunological and hematological tests. Birds were opened to examine abdominal cavity and to collect the immune organs (Bursa, Thymus and Spleen) to record their weight. From collected blood serum was separated to check the antibody titer.

Data was collected through this trial that was based on Randomized control based design. It can be undergo further evaluation by Minitab Inc. 2010. Minitab Statistical Software (Release 17), State College, PA [21].

\section{Results}

The total body weight per broiler chick at the end of trial was 857, 1393, 1355 and 2038 grams fed diet $\mathrm{A}, \mathrm{B}, \mathrm{C}$ and $\mathrm{D}$ respectively and was significant $(\mathrm{P}<0.001)$ with maximum weight gain in broilers fed diet $\mathrm{D}$ while lowest weight gain in birds fed diet A (Table 3).

Table 3. Growth performance of broilers fed experimental diets

\begin{tabular}{|c|c|c|c|c|c|}
\hline DAY & $\begin{array}{l}\text { MOLM } \\
0 \%\end{array}$ & $\begin{array}{l}\text { MOLM } \\
2 \%\end{array}$ & $\begin{array}{l}\text { MOLM } \\
4 \%\end{array}$ & $\begin{array}{l}\text { MOLM } \\
6 \%\end{array}$ & P-Value \\
\hline \multicolumn{6}{|c|}{ Bursa weight (grams) } \\
\hline 7 & - & - & - & - & - \\
\hline 14 & 0,362 & 0,342 & 0,341 & 0,420 & ${ }^{\mathrm{NS}} 0,470$ \\
\hline 21 & $0,094^{\mathrm{ab}}$ & $0,067^{\mathrm{b}}$ & $0,110^{\mathrm{ab}}$ & $0,139^{\mathrm{a}}$ & $* 0,015$ \\
\hline 28 & - & - & - & - & - \\
\hline 35 & $0,066^{\mathrm{a}}$ & $0,073^{\mathrm{a}}$ & $0,633^{\mathrm{a}}$ & $0,099^{\mathrm{a}}$ & ${ }^{\mathrm{NS}} 0,413$ \\
\hline \multicolumn{6}{|c|}{ BW (grams) } \\
\hline 7 & 189 & 201 & 218 & 217 & ${ }^{\mathrm{NS}} 0,129$ \\
\hline 14 & 538 & 455 & 543 & 490 & $* 0,05$ \\
\hline 21 & $1035^{\mathrm{ab}}$ & $843^{b}$ & $1116^{\mathrm{a}}$ & $1049^{\mathrm{ab}}$ & $* 0,019$ \\
\hline 28 & $1414^{\mathrm{a}}$ & $836^{\mathrm{c}}$ & $1094^{\mathrm{bc}}$ & $1149^{\mathrm{ab}}$ & 0,002 \\
\hline 35 & $2363^{a}$ & $1032^{\mathrm{c}}$ & $1445^{\mathrm{b}}$ & $1375^{\mathrm{b}}$ & $* * * 0,001$ \\
\hline \multicolumn{6}{|l|}{ FCR } \\
\hline 7 & 1,23 & 1,04 & 0,95 & 0,83 & ${ }^{\mathrm{NS}} 0,209$ \\
\hline 14 & 1,6 & 1,29 & 1,21 & 1,39 & ${ }^{\mathrm{NS}} 0,069$ \\
\hline 21 & $2,92^{\mathrm{a}}$ & $1,73^{b}$ & $1,48^{\mathrm{b}}$ & $1,66^{\mathrm{b}}$ & $* * 0,009$ \\
\hline 28 & $4,38^{\mathrm{a}}$ & $2,82^{\mathrm{ab}}$ & $2,30^{c}$ & $2,65 b^{c}$ & $* * 0,007$ \\
\hline 35 & 5,26 & 3,89 & 2,69 & 3,45 & $* 0,148$ \\
\hline \multicolumn{6}{|c|}{ Feed Intake (grams) } \\
\hline 7 & 229 & 209 & 204 & 179 & $* 0,474$ \\
\hline 14 & $858^{\mathrm{a}}$ & $583^{b}$ & $657^{\mathrm{b}}$ & $681^{b}$ & $* * 0,006$ \\
\hline 21 & $2980^{\mathrm{a}}$ & $1452^{\mathrm{b}}$ & $1658^{\mathrm{b}}$ & $1732^{b}$ & $* * 0,005$ \\
\hline 28 & $6250^{\mathrm{a}}$ & $2328^{b}$ & $2509^{b}$ & $3058^{b}$ & $* * 0.003$ \\
\hline 35 & $12836^{\mathrm{a}}$ & $4002^{b}$ & $3961^{\mathrm{c}}$ & $4780^{b}$ & $* 0.048$ \\
\hline
\end{tabular}

The average feed intake in grams per broiler chick was $3089,3575,3785$, and 3982 fed $\operatorname{diet}$ A, B, C and $\mathrm{D}$ respectively and was significant $(\mathrm{P}<0.001)$ with maximum feed intake in broilers fed diet $\mathrm{D}$ while lowest feed intake in birds fed diet A (Table $3)$.

The average feed conversion ratio per broiler chick was $1.79,1.74,1.73$ and 1.76 for $\mathrm{A}, \mathrm{B}, \mathrm{C}$ and $\mathrm{D}$, respectively and was significant $(\mathrm{P}<0.001)$ with diet $\mathrm{C}$ whereas the highest FCR in broilers was with diet without Moringa oleifera supplementations (Table 3).

Table 4. Immunological parameters of broilers fed experimental diets

\begin{tabular}{|c|c|c|c|c|c|}
\hline \multicolumn{6}{|c|}{ HA/HI titer } \\
\hline 7 & 170 & 213 & 256 & 256 & ${ }^{\mathrm{NS}} 0,219$ \\
\hline 14 & 18,667 & 69,33 & 29,33 & 98,667 & ${ }^{\mathrm{NS}} 0,571$ \\
\hline 21 & $341,333^{\mathrm{ab}}$ & $341,333^{\mathrm{a}}$ & $149,333^{b}$ & $128,000^{\mathrm{ab}}$ & $* 0,014$ \\
\hline 28 & $170,667^{\mathrm{a}}$ & $213,333^{\mathrm{a}}$ & $256^{\mathrm{a}}$ & $256^{\mathrm{a}}$ & ${ }^{\mathrm{NS}} 0,219$ \\
\hline 35 & $1024,00^{\mathrm{a}}$ & $554,67^{\mathrm{ab}}$ & $298,67^{b}$ & $213,33^{b}$ & $* 0,016$ \\
\hline \multicolumn{6}{|c|}{ Hemoglobin concentration } \\
\hline 7 & - & - & - & - & - \\
\hline 14 & 6,5 & 9,4 & 7.03 & 7,53 & ${ }^{\mathrm{NS}} 0,137$ \\
\hline 21 & $9,8667^{\mathrm{a}}$ & $10,633^{\mathrm{a}}$ & $10.466^{\mathrm{a}}$ & $9,400^{\mathrm{a}}$ & ${ }^{\mathrm{NS}} 0,395$ \\
\hline 28 & - & - & - & - & - \\
\hline 35 & $10,766^{\mathrm{a}}$ & $8,733^{\mathrm{a}}$ & $9,800^{\mathrm{a}}$ & $10,700^{\mathrm{a}}$ & $* 0,041$ \\
\hline \multicolumn{6}{|c|}{ Mortality \% } \\
\hline 7 & $22,22^{\mathrm{a}}$ & $8,33^{\mathrm{b}}$ & $8,33^{b}$ & $8,33^{\mathrm{b}}$ & $* * * 0,001$ \\
\hline 14 & $47,22^{\mathrm{a}}$ & $19,44^{\mathrm{b}}$ & $16,67^{b}$ & $19,44^{b}$ & $* * * 0,001$ \\
\hline 21 & $66,67^{\mathrm{a}}$ & $30,56^{\mathrm{b}}$ & $36,11^{b}$ & $38,89^{b}$ & $* * * 0,001$ \\
\hline 28 & $75^{\mathrm{a}}$ & $38,89^{\mathrm{b}}$ & $38,89^{\mathrm{b}}$ & $47,22^{b}$ & $* * 0,007$ \\
\hline 35 & $83,33^{\mathrm{a}}$ & $52,78^{b}$ & $50^{b}$ & $58,33^{\mathrm{b}}$ & $* 0,034$ \\
\hline \multicolumn{6}{|c|}{ PCV } \\
\hline 7 & - & - & - & - & - \\
\hline 14 & 22 & 27 & 20 & 21 & ${ }^{\mathrm{NS}} 0,377$ \\
\hline 21 & $18,667^{b}$ & $32,667^{\mathrm{a}}$ & $31,333^{\mathrm{a}}$ & $27,666^{\mathrm{ab}}$ & $* 0,014$ \\
\hline 28 & - & - & - & - & - \\
\hline 35 & $32,667^{\mathrm{a}}$ & $26,667^{\mathrm{a}}$ & $24,667^{\mathrm{a}}$ & $29,000^{\mathrm{a}}$ & ${ }^{\mathrm{NS}} 0,083$ \\
\hline \multicolumn{6}{|c|}{ Spleen weight (grams) } \\
\hline 7 & - & - & - & - & - \\
\hline 14 & 0,482 & 0,324 & 0,279 & 0,32 & ${ }^{\mathrm{NS}} 0,321$ \\
\hline 21 & $0,104^{\mathrm{a}}$ & $0,0736^{\mathrm{a}}$ & $0,040^{\mathrm{a}}$ & $0,089^{\mathrm{a}}$ & ${ }^{\mathrm{NS}} 0,22$ \\
\hline 28 & - & - & - & - & - \\
\hline 35 & $0,073^{b}$ & $0,076^{\mathrm{b}}$ & $0,087^{b}$ & $0,193^{\mathrm{a}}$ & $* * * 0,001$ \\
\hline \multicolumn{6}{|c|}{ Thymus weight (grams) } \\
\hline 7 & - & - & - & - & - \\
\hline 14 & 0,350 & 0,316 & 0,269 & 0,301 & ${ }^{\mathrm{NS}} 0,369$ \\
\hline 21 & $0,081^{\mathrm{a}}$ & $0,060^{\mathrm{a}}$ & $0,112^{\mathrm{a}}$ & $0,141^{\mathrm{a}}$ & ${ }^{\mathrm{NS}} 0,131$ \\
\hline 28 & - & - & - & - & - \\
\hline 35 & $0,058^{\mathrm{a}}$ & $0,124^{\mathrm{a}}$ & $0,124^{\mathrm{a}}$ & $0,082^{\mathrm{a}}$ & ${ }^{\mathrm{NS}} 0,173$ \\
\hline
\end{tabular}

The average $\log _{2}$ value of ND HI titer against NDV were 7,00, 6,00, 7,44, 7,20 and 7,17 under different groups of A, B, C and D respectively and was significant $(\mathrm{P}<0.001)$ with highest antibody level in the birds of group $\mathrm{C}$, while lowest level was found in the broilers of group B (Table 4).

The relative weight of spleen per broiler chick was $0,057,0,328,0,285$ and 0,35 grams at Day 
14; $0,057,0,070,0,091$ and 0,130 grams at day $21 ; 0,087,0,066,0,097$ and 0,057 grams at day 35 that were fed with diets $\mathrm{A}, \mathrm{B}, \mathrm{C}$ and $\mathrm{D}$ respectively, and were not significant $(\mathrm{P}>0,05)$ (Table 4).

The relative thymus weight per broiler chick was $0,406,0,285,0,209$ and 0,457 grams at day 14 ; $0,065,0,044,0,082$ and 0,115 grams at Day 21; $0,071,0,145,0,080$ and 0,086 grams at Day 35 fed diets $\mathrm{A}, \mathrm{B}, \mathrm{C}$ and $\mathrm{D}$ respectively and were not significant $(\mathrm{P}>0,05)$ (Table 4$)$.

The relative weight of Bursa of Fabricius per broiler chick was $0,460,0,322,0,367$ and 0,457 grams at Day 14; 0,067, 0,094, 0,091 and 0,130 grams Day 21;0,078, 0,038, 0,073 and 0,142 grams at Day 35 fed diets A, B, C and D respectively and was not significant $(\mathrm{P}<0.05)$ (Table 4).

Packed cell volume of blood serum of broiler was 16, 30, 18 and $19 \%$ at Day 14; 21, 31, 33 and 28 $\%$ at Day 21; 29, 24, 23 and $30 \%$ at Day 35, fed diets $\mathrm{A}, \mathrm{B}, \mathrm{C}$ and $\mathrm{D}$ respectively and was significant $(\mathrm{P}<0.001)$ (Table 4).

The hemoglobin $(\mathrm{g} / \mathrm{dL})$ of blood serum of broiler was 4,$9 ; 8,3,6,9$ and 5,9 at Day $14 ; 7,9,10,4,10$ and 8,9 at Day 21;10,6, 7,2, 9 and 10,7 at Day 35, fed diets $A, B, C$ and $D$ respectively and was not significant $(\mathrm{P}>0.05)$ (Table 4).

\section{Discussion}

Ayssiwede [18] studied that Moringa oleifera extract up to ratio of $25 \%$ used in poultry feed did not cause any negative effects in substitution of ground nut cake meal. Mahmood [22] studied cichorium intybus, Azadirachta indica and Moringa oleifera and concluded that the Moringa oleifera leaves indicate better immunomodulatory results as compared to the control group.

Similar results were found by Gadzirayi [23] study was investigated that Moringa oleifera leaf meal (MOLM) with soybean supplements used as a protein source in poultry. The total body weight data showed that there was significant difference $(\mathrm{P}<0.001)$ in weight gain of broilers between different groups at the end of trial.

Melesse [24] indicated that Moringa stenopetala leaf meal MSLM is a potential plant protein supplement and could be included to $6 \%$ in the diet of grower chicks to substitute expensive conventional protein sources and there was significant difference $(\mathrm{P}<0.001)$ in feed conversion ratio of broilers fed diets $\mathrm{A}, \mathrm{B}, \mathrm{C}$ and $D$ at the end of trial. Similar results were found by Banjo [25] whose results showed that Inclusion of Moringa oleifera significantly enhanced weight gain of birds at $4 \%$ level of inclusion the most. The inclusion of Moringa oleifera did not significantly enhance feed intake and feed conversion ratio despite the total body weight increments.

In the present study, the $\mathrm{HI}$ antibody titers against NDV were tested. The analysis of variance of the antibody titers amongst all groups in pair wise tests revealed that there was highly significant effect $\quad(\mathrm{P}<0.001)$ of Moringa oleifera supplementation on ND HA/HI titers. The highest antibody level was found in the birds of group B, while lowest level was found in the broilers of group D. Similar results were found by a study of Mahmood [22], and they demonstrated that Feed intake, weight gain and FCR was better in group $B$ fed respecting supplemented diet $(\mathrm{P}<0.05)$ whilst immune response against ND. There was no significant difference $(\mathrm{P}>0.05)$ in spleen weight of broilers among different groups in this experiment. An interesting observation in this study was that Moringa oleifera does increase the parameters but in a non-dose dependent manner and the effect seems to plateau out somewhere around 4 grams per kilogram of feed.

Supplementation of Moringa oleifera leaves with inactivated vaccine did not prevent the atrophy of bursa, spleen and harderian gland against the negative effect of vv IBDV 7 days post infection [27]. It was thus concluded that the immunomodulatory effect of Moringa oleifera does not exceed the physiological limitations while optimizing the immunological parameters and can be an exceptional ameliorant when added as a supplement to the commercial and backyard poultry.

In a nutshell, the aim of present study was to assess the effect of varying levels of immunogenic response of Moringa oleifera supplementation broiler against the Newcastle Disease vaccine. 144 day-old chicks (Male and Female mixed) with average weight of $46,78 \mathrm{~g}$ were selected for this experiment. Chicks were divided into four groups; A, B, C and D with 3 replicates consisting of 12 birds each in all groups using Completely Randomized Design as the driving statistical model. Diet D was without any supplementation of Moringa oleifera, diet A was supplemented with $2 \%$ Moringa oleifera, diet B was 
supplemented with $4 \%$ Moringa oleifera, diet C was supplemented with $6 \%$ Moringa oleifera. The study was conducted for a period of 35 days. Daily feed intake and fortnightly weight gain were recorded during the experimental period. The blood samples from each group were collected at day of 14, 21 and 35 after slaughtering experiment birds and weight of lymphoid organs and hematology parameters were observed.

During 1 to 35 days, best FCR was found for experimental diet $\mathrm{C}$ and Highest $\mathrm{HI}$ titer against NDV was observed for experimental diet A and B with supplemented with $2 \%$ Moringa oleifera, diet B was supplemented with $4 \%$ respectively. Among the weight of lymphoid organs, the weight of Bursa was highest for experimental diet C. No significant difference was observed for the weight of other body organs. At day $14^{\text {th }}$ and 21th day, $\mathrm{PCV}$ was significant $(\mathrm{P}<0.001)$. Maximum PCV was in group B and lowest PCV was in group A. Maximum hemoglobin was in group $\mathrm{B}$ and $\mathrm{C}$ and minimum hemoglobin $(\mathrm{g} / \mathrm{dL})$ was in group $\mathrm{A}$.

At day $35^{\text {th }}$, PCV data was significant $(\mathrm{P}<0.001)$ with maximum PCV in group D and lowest PCV was in group $\mathrm{C}$ and maximum hemoglobin in group $\mathrm{D}$ and minimum hemoglobin $(\mathrm{g} / \mathrm{dL})$ in group C. Form present study it may concluded that supplementation of Moringa oleifera imparts positive effect on growth performance of birds, hematological and immunological effects in birds and antibody titer against ND and it can be recommended as an ameliorative supplement.

\section{References}

[1] Khalifa KA., Abedlrahim ES., Elnasri IM., Ahmed SO. A retrospective study (20002005) of poultry diseases diagnosed at department of avian diseases and diagnosis, Veterinary Research Institute (VRI)-Khartoum. Sudanese J of Anim Sci 2013; 9: 42-45.

[2] Raza A, Muhammad F, Bashir S, Anwar MI, Awais MM, Akhtar M., Naseer MU. Antiviral and immune boosting activities of different medicinal plants against Newcastle disease virus in poultry, World's Poultry Science Journal 2015; 71(3): 523-532.

[3] Fahey JW. Moringa Pleifera: A review of the medical evidence for its nutritional, therapeutic and prophylactic. Properties, part 1. Trees for Life Journal 2005; 1-5.
[4] Aruna M., Srilatha N. Water clarification using Moringa oleifera Lam. seed as a natural coagulant, Current Biotica 2012; 5(4): 472-486.

[5] Ikubanni PP., Komolafe OO, Agboola OO., Osueke CO. Moringa seed dehulling machine: a new conceptual design. Journal of Production Engineering 2017; 20(2): 73-78.

[6] Yameogo C., Bengaly M., Savadogo A., Nikiema P., Traore S. Determination of chemical composition and nutritional values Moringa oleifera leaves, Pak J Nutr 2011; 10: 264-268.

[7] Ezejindu DN, Akiingboye AJ. Protective effects of Moringa oleifera leaf extract on murcury induced spleenotoxity in adult wistar rats, Int Mult-dis e- J 2014; 3: 57- 63.

[8] Perez A., Sánchez T., Armengol N., Reyes F. Characteristics and potential of Moringa oleifera, Lamark. An alternative for animal feeding. Price, M.L. 2007. The Moringa Tree. Echo Technical Note.

[9] Orwa C., Mutua A., Kindt R., Jamnadass R., Anthony S. Agro-forestry Database: a tree reference and selection guide version 4.0. World Agro-forestry Centre, Kenya. 2009; 335-336.

[10] Gaia S. Wonder tree 100 facts Moringa fact 04 exceptional animal feed Moringa as livestock feed \& pet food, Moringa Mission Trust. 2005.

[11] Khalafalla MM., Abdellatef E., Dafalla HM., Nassrallah AA., Aboul-Enein KM., Lightfoot DA. Active principle from Moringa oleif.era Lam Leaves effective against two leukemias and a hepatocarcinoma, African Journal of Biotechnology 2010; 9: 8467-8471.

[12] Anamika G., Manish K., Rahul K., Rao C., Goel R., Shampa A. Immunumodulatory effect of Moringa oleifera Lam. extract on cyclophosphamide induced toxicity in mice, Indian Journal of Experimental Biology 2010; 48: 1157-1160.

[13] Fuglier LJ. The miracle tree: Moringa oleifera. Natural nutrition for the tropics. Church World Service, Dakkar, Senegal, 1999; 68.

[14] Feustel S., Ayon-Perez F., SandovalRodriguez A., Rodriguez-Echevarria R., Contreras-salinas H., Armendarz-Borunda J., Sanchez-Orozco LV. Protective effects of 
moringa oleifera on hbv genotypes $\mathrm{c}$ and $\mathrm{h}$ transiently transfected huh7 cells, Journal of Immunology Research, 2017.

[15] Teixeira EMB., Carvalho MRB., Neves VA., Silva MA., Arantes-Pereira L. Chemical characteristics and fractionation of proteins from Moringa oleifera lam. leaves, Food Chemistry 2014; 147: 51-54.

[16] Gakuya DW., Mbugua PN., Kavoi B., Kiama SG. Effect of supplementation of Moringa oleifera leaf meal in broiler chicken feed, International Journal of Poultry Science 2014; 13: 208-213.

[17] Nouman W., Basra SMA., Siddiqui MT., Yasmeen A., Gull T., Alcayde MAC. Potential of Moringa oleifera L. as livestock fodder crop: a review, Turkish Journal of Agriculture and Forestry 2013; 37: 1-1.

[18] Ayssiwede S., Dieng A., Bello H., Chrysostome CAAM., Hane MB., Mankor A., Missohou A. Effects of Moringa oleifera (Lam.) leaves meal incorporation in diets on growth performances, carcass characteristics and economics results of growing indigenous Senegal chicken, Pakistan Journal of Nutrition 2011; 10(12): 1132-1145.

[19] Yan Z., Du Y., Zhao Q., Fan R., Guo W., Ma R., Wang X., Zhu R. Mucosal immune responses against live newcastle disease vaccine in immunosuppressed chickens, Pak Vet J 2011; 31: $280-286$.

[20] Benjamin MH. Outline of Veterinary Clinical Pathology. 3rd ed., Iowa State University Press, Ames, U.S.A, 1978; 38-40.

[21] Minitab INC. Minitab 16 statistical software. URL:[Computer software]. State College, PA: Minitab, Inc. http://www.minitab.com/en-us/, 2010.

[22] Mahmood S., Rehman A., Yousaf M., Akhtar P., Abbas G., Hayat K., Shahzad MK. Comparative efficacy of different herbal plant's leaf extract on haematology, intestinal histomorphology and nutrient digestibility in broilers, Adv Zool Bot 2015; 3(2): 11-16.

[23] Gadzirayi CT., Masamha B., Mupangwa JF., Washaya S. Performance of broiler chickens fed on mature Moringa oleifera leaf meal as a protein supplement to soyabean meal, Inter $\mathrm{J}$ of $\mathrm{P}$ Sci 2012; 11(1): 5-10.

[24] Melesse A., Tiruneh W., Negesse T. Effects of feeding Moringa stenopetala leaf meal on nutrient intake and growth performance of Rhode Island Red chicks under tropical climate, Trop Subtrop Agroeco 2011; 14: 485-492.

[25] Banjo OS. Growth and performance as affected by inclusion of Moringa oleifera leaf meal in broiler chicks diet, J. of Bio Agri Healthcare 2012; 2: 35-39.

[26] Mahmood S., Hayat K., Yousaf M., Abbas G., Rehman A. Comparative effect of Azadirachta indica, Moringa oleifera and Cichorium intybus leaf extracts on growth performance, immune response and carcass characteristics of broilers, Scholar's Adv. Anim. Vet. Res 2016; 3: 60-65.

[27] Balami AG., Abdu PA., Wakawa AM., Aluwong T. The effect of very virulent infectious bursal disease virus on immune organs of broilers fed moringa oleifera supplemented feed, World 2016; 6(3): 95-100. 